\title{
PENGARUH MODEL PEMBELAJARAN KOOPERATIF TIPE THINK - PAIR - SHARE ( TPS ) TERHADAP KEMAMPUAN KOMUNIKASI MATEMATIS SISWA KELAS VIII SMP NEGERI 4 BINJAI TAHUN PELAJARAN 2017/2018 \\ Kiki Kesuma Rahayu ${ }^{1}$, Ice Wirevenska ${ }^{2}$ \\ STKIP Budidaya Binjai. Jl. Gaharu Binjai \\ Email : Ice.wr08@gmail.com
}

\begin{abstract}
ABSTRAK
Masalah yang terlihat dalam penelitian ini yaitu 1) Kemampuan komunikasi matematis siswa SMPN 4 Binjai masih tergolong rendah; 2) Siswa tidak mampu mengemukakan pendapatnya; dan 3) Model pembelajaran yang digunakan belum sesuai. Tujuan penelitian ini adalah Untuk mengetahui pengaruh model pembelajaran kooperatif tipe Think - Pair - Share (TPS) terhadap kemampuan komunikasi matematis siswa kelas VIII SMP Negeri 4 Binjai tahun pelajaran 2017/2018. Penelitian ini laksanakan SMP Negeri 4 Binjai jalan Bejomuna Kel.Timbang Langkat di Kelas VIII Tahun Pelajaran 2017/2018. Jenis penelitian yang digunakan adalah penelitian eksperimen semu (quasi experimental), sampel yang di ambil dalam penelitian ini dengan cara simple random sampling, dengan unit samplingnya adalah kelas $\mathrm{VIII}_{1}, \mathrm{VIII}_{2}, \mathrm{VIII}_{3}$ dan $\mathrm{VIII}_{4}$. Pada penelitian ini, terpilih kelas $\mathrm{VIII}_{2}$ sebagai kelompok eksperimen dan kelas $\mathrm{VIII}_{4}$ sebagai kelompok kontrol dengan jumlah sampel 60 siswa. Kelompok eksperimen akan diberikan perlakuan berupa pembelajaran kooperatif tipe TPS (Think-Pair-Share) sedangkan kelompok kontrol akan diberikan pembelajaran konvensional. Instrumen yang digunakan dalam penelitian ini berupa tes kemampuan komunikasi matematis siswa. Tes digunakan untuk mengukur kemampuan komunikasi matematis siswa yang terdiri lima butir soal. Data yang diperoleh terdiri dari nilai kognitif pemahaman konsep matematika. Data awal tersebut berupa nilai tes kemampuan awal yaitu nilai matematika pretest dan nilai tes akhir pada materi aljabar yang dianalisis dengan menggunakan uji normalitas, uji homogenitas, uji kesamaandua rata-rata dan uji hipotesis. Berdasarkan perhitungan terlihat bahwa $\mathrm{r}_{\text {hitung }}>\mathrm{r}_{\text {tabel }}(5,00>4,13)$. Pengujian hipotesis dilakukan dengan uji $\mathrm{t}$ bahwa $t_{\text {hitung }}>t_{\text {tabel }}(6,488>1,665)$ maka hipotesis $H_{a}$ diterima, sehingga terdapat pengaruh model pembelajaran kooperatif tipe Think - Pair - Share ( TPS ) terhadap kemampuan komunikasi matematis siswa kelas VIII SMP Negeri 4 Binjai Tahun Pelajaran 2017/2018.
\end{abstract}

Kata Kunci : Think-Pair-Share, Komunikasi Matematis 


\section{PENDAHULUAN}

Kemampuan komunikasi matematis merupakan kemampuan menyampaikan gagasan dengan simbol-simbol, grafik atau diagram untuk menjelaskan keadaan atau masalah yang terdapat dari suatu masalah atau pertanyaan yang diberikan dari suatu materi pelajaran yang di ajarkan guru di sekolah.

Baroody (dalam Wirevenska, 2013) menyebutkan sedikitnya ada dua alasan penting mengapa komunikasi matematik perlu ditumbuhkembangkan dikalangan siswa. Pertama, mathematics as language, artinya matematika tidak hanya sekedar alat bantu berpikir, alat untuk menemukan pola, menyelesaikan masalah atau mengambil kesimpulan, tetapi matematik juga sebagai alat yang berharga untuk mengkomunikasikan berbagai ide secara jelas dan cermat. Kedua, mathematics learning as social activity. Artinya sebagai aktivitas sosial dalam pembelajaran matematika, matematika juga sebagai wahana interaksi antar siswa, dan juga komunikasi antar guru dan siswa. Akan tetapi di kehidupan nyata matematika yang diajarkan guru di sekolah masih belum bisa membangkitkan kemampuan komunikasi matematis siswa dalam menyelesaikan setiap masalah atau tugas yang diberikan guru kepadanya.

Dari hasil observasi yang dilakukan di SMP Negeri 4 Binjai peneliti memberikan tes pendahuluan untuk mengukur pengetahuan awal siswa. Berdasarkan hasil tes untuk materi aljabar pada kelas IX di SMP Negeri 4 Binjai diketahui bahwa masih banyak siswa/i yang mengalami kesulitan dalam

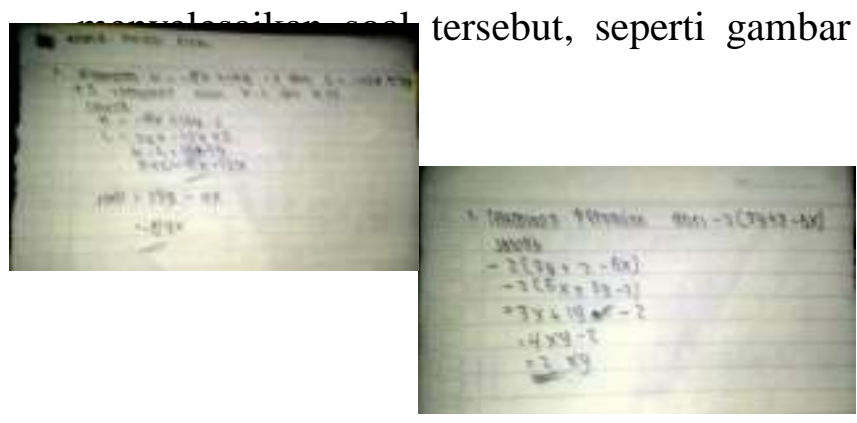

Gambar 1. Hasil kerja siswa

Bila diperhatikan dari hasil tes pendahuluan yang peneliti berikan pada saat observasi di kelas IX SMP Negeri 4 Binjai diperoleh informasi bahwa kemampuan komunikasi matematis siswa masih tergolong rendah. Dari 62 siswa yang mengikuti tes diperoleh bahwa 11 siswa (17\%) yang dapat menjelaskan ide mereka secara tertulis tetapi masih belum benar hasilnya, 16 siswa (25\%) dapat menyelesaikan soal dengan jawaban yang benar, 5 siswa (8\%) tidak menjawab sama sekali, dan $50 \%$ siswa yang menjawab tetapi tidak dapat menjelaskan ide mereka. Hasil tersebut membuktikan bahwa 
kemampuan komunikasi matematis siswa dalam menyelesaikan soal aljabar tersebut masih rendah. Berdasarkan hasil wawancara peneliti dengan salah satu siswa bernama Echa Revina mengenai seberapa besar keinginannya dalam mengikuti pelajaran matematika, Echa Revina mengatakan bahwa metode yang digunakan guru ketika mengajar terasa membosankan dan membuat siswanya kurang mendengarkan penjelasan gurunya ketika proses belajar dilaksanakan. Sehingga nilai rata - rata siswa pada tes pendahuluan tersebut $<70$, sedangkan nilai ketuntasan atau KKM yang digunakan adalah $\geq 70$. Oleh karena itu dalam proses pembelajaran matematika diperlukan suatu metode mengajar yang bervariasi. Artinya penggunaan metode mengajar yang tidak harus sama untuk setiap pokok bahasan karena setiap metode mengajar belum tentu cocok untuk satu pokok bahasan dengan pokok bahasan yang lain.

Dari penjelasan tersebut dapat di simpulkan bahwa kemampuan komunikasi matematis siswa SMP Negeri 4 Binjai masih sangat rendah dan nilai yang diterima siswa masih dibawah KKM. Maka dalam penelitian ini model pembelajaran yang digunakan adalah model pembelajaran kooperatif. Model pembelajaran kooperatif ialah model pembelajaran yang melibatkan partisipasi siswa dalam suatu kelompok kecil umtuk saling berinteraksi atau berdiskusi.
Dalam penelitian ini model pembelajaran kooperatif yang peneliti gunakan ialah model pembelajaran kooperatif tipe Think - Pair - Share ( TPS ). Model TPS ialah model yang memberikan kesempatan kepada siswa untuk bekerja sendiri serta bekerja sama dengan orang lain baik itu teman sebangkunya, maupun teman sekelasnya. Model ini lebih mengutamakan aktifitas siswa dalam proses pembelajaran dan memberi siswa lebih banyak waktu untuk berfikir, merespon dan saling membantu, tidak membutuhkan waktu yang lama untuk membentuk kelompok, dan guru dapat dengan mudah memantau aktifitas siswanya.

Berdasarkan uraian diatas, maka diperlukan upaya peningkatan kemampuan komunikasi matematis siswa di dalam proses pembelajaran matematika dan salah satu model pembelajaran yang dapat meningkatkan kemampuan komunikasi matematis serta sikap siswa terhadap matematika adalah model pembelajaran kooperatif tipe Think - Pair - Share (Tps). Hal itulah yang mendorong penulis sebagai pengajar tertarik untuk melakukan penelitian yang berjudul, "Pengaruh Model Pembelajaran Koperatif Tipe Think - PairShare (TPS) terhadap Kemampuan Komunikasi Matematis Siswa Kelas VIII SMP Negeri 4 Binjai Tahun Pelajaran 2017/2018". 


\section{METODE PENELITIAN}

Populasi dalam penelitian ini adalah seluruh siswa kelas VIII SMP Negeri 4 Binjai Tahun pelajaran 2017/2018 sebanyak 4 kelas, yaitu kelas $\mathrm{VIII}_{1}, \mathrm{VIII}_{2}, \mathrm{VIII}_{3}$, dan $\mathrm{VIII}_{4}$, dimana jumlah keseluruhan populasinya adalah 121 siswa. Sampel yang di ambil dalam penelitian ini dengan cara simple random sampling, yang terdiri dari 60 siswa kelas $\mathrm{VIII}_{2}$ dan $\mathrm{VIII}_{4}$. Kelas $\mathrm{VIII}_{2}$ sebagai kelas eksperimen dan kelas $\mathrm{VIII}_{4}$ sebagai kelas kontrol. Kelompok eksperimen mendapatkan perlakuan berupa pembelajaran aljabar dengan model pembelajaran kooperatif tipe Think-Pair-Share (TPS) dan kelompok kontrol mendapatkan perlakuan berupa pembelajaran konvensional.

Jenis penelitian ini merupakan penelitian eksperimen semu (quasi experimental. Penelitian ini bertujuan untuk mengetahui pengaruh model pembelajaran kooperatif tipe Think- Pair - Share (TPS) terhadap kemampuan komunikasi matematis siswa.

\section{WAKTU DAN TEMPAT PENELITIAN}

Penelitian ini di laksanakan di SMP Negeri 4 Binjai Jalan Bejomuna Kel. Timbang Langkat di Kelas VIII Tahun Pelajaran 2017/2018. Beberapa alasan peneliti memilih sekolah ini menjadi tempat penelitian antara lain : 1) belum pernah ada penelitian yang sejenis ini dilakukan di sekolah tersebut,
2) berdasarkan hasil tes studi pendahuluan yang di lakukan terlihat bahwa kemampuan komunikasi matematis siswa di sekolah ini rendah.

Penelitian ini dilaksanakan pada semester I Tahun Pelajaran 2017/2018, mulai dari bulan Oktober. Penetapan jadwal penelitian disesuaikan dengan jadwal yang telah ditetapkan oleh pihak sekolah, dimana waktu belajar matematika disediakan 5 (lima) jam pelajaran. Adapun materi pelajaran yang dipilih dalam penelitian ini adalah aljabar yang merupakan materi kelas VIII yang sedang dipelajari pada semester tersebut.

\section{HASIL DAN PEMBAHASAN}

1. Data Pretest Kemampuan

Komunikasi Matematis Siswa kelas

\section{Eksperimen dan Kelas Kontrol}

Sebelum melakukan pembelajaran pada kedua kelas dengan pembelajaran yang berbeda yakni dengan model pembelajaran Think Pair Share (TPS) dan model pembelajaran konvensional, terlebih dahulu diadakan pretest untuk mengetahui kemampuan awal siswa khususnya kemampuan komunikasi matematis siswa dari kedua kelas tersebut.

Tabel 4.1 Statistik Distributif Pretest Kelas

Eksperimen Dan Kelas Kontrol

\begin{tabular}{|l|c|c|}
\hline No & Ukuran & Pretest \\
\hline
\end{tabular}




\begin{tabular}{|c|l|c|c|}
\hline & \multicolumn{1}{|c|}{ Statistik } & $\begin{array}{c}\text { Kelas } \\
\text { Eksperimen }\end{array}$ & $\begin{array}{c}\text { Kelas } \\
\text { Kontrol }\end{array}$ \\
\hline 1 & Jumlah Siswa & 30 & 30 \\
\hline 2 & Jumlah Skor & 1530 & 1383 \\
\hline 3 & Skor Maksimum & 80 & 75 \\
\hline 4 & Skor Minimum & 13 & 21 \\
\hline 5 & Rata-Rata & 51,00 & 46,1 \\
\hline 6 & Simpangan Baku & 18,82 & 15,77 \\
\hline 7 & Varians & 354,19 & 248,69 \\
\hline
\end{tabular}

Pada tabel diatas terlihat bahwa hasil perhitungan pretest pada kelas eksperimen diperoleh nilai varians 354,19 , simpangan baku 18,82. Sedangkan pada kelas kontrol diperoleh nilai varians 248,69 dan simpangan bakunya yaitu 15,77. Hasil pemberian pretest diperoleh nilai rata-rata dikelas eksperimen 51,00 dan hasil pemberian nilai pretest pada kelas kontrol diperoleh nilai rata-rata 46,1. Perbedaan nilai rata-rata siswa antara kelas eksperimen dengan kelas kontrol menunjukkan homogen yang berarti kemampuan awal sama. Hal ini juga dibuktikan dengan Uji F (Lampiran 29) yaitu diperoleh $F_{\text {hitung }}=1,42$ dan $\quad F_{\text {tabel }}=1,86$. Karena $F_{\text {hitung }}<F_{\text {tabel }}$ yaitu $1,42<1,86$ maka $\mathrm{H}_{\mathrm{o}}$ diterima dan $\mathrm{H}_{\mathrm{a}}$ ditolak dan disimpulkan tidak terdapat perbedaan kemampuan awal antara siswa kelas eksperimen dengan kelas kontrol.

Secara visual penyebaran data kemampuan komunikasi matematis siswa kelas eksperimen yang menggunakan model pembelajaran Think Pair Share (TPS) dan kelas kontrol yang menggunakan model pembelajaran konvensional dapat dilihat pada histogram perbedaan nilai rata-rata, simpangan baku, dan varians pretest kelas eksperimen dan kelas kontrol sebagai berikut.

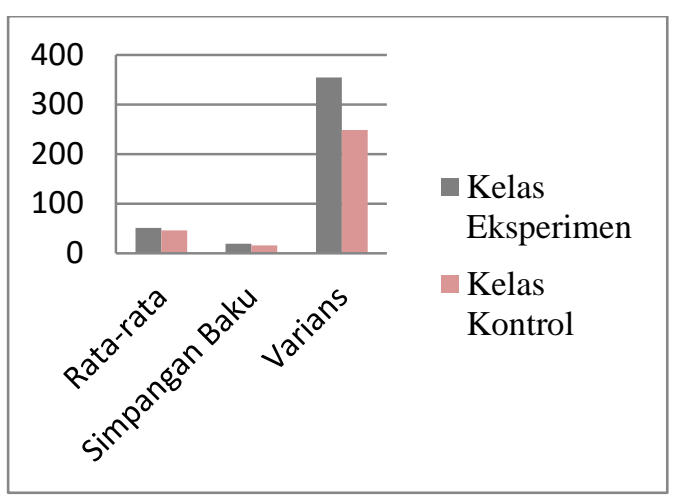

Gambar 4.1 Perbedaan Rata-Rata, Simpangan Baku, Dan Varians Pretest

\section{Kelas Eksperimen Dan Kelas Kontrol}

Gambar 4.2 adalah gambar perbedaan rata-rata, simpangan baku, dan varians kelas eksperimen dan kelas kontrol. Dimana ratarata kelas eksperimen adalah 61,53 dan 54,00 untuk kelas kontrol, simpangan baku kelas eksperimen adalah 15,81 dan 15,51 untuk kelas kontrol, sedangkan varians kelas eksperimen adalah 249,96 dan 240,56 untuk kelas kontrol.

\section{Uji Normalitas}

Uji normalitas yang digunakan adalah uji Liliefors. Uji Liliefors digunakan untuk mengetahui apakah data berasal dari populasi yang berdistribusi normal atau tidak, dengan ketentuan bahwa data berasal dari populasi yang berdistribusi normal jika memenuhi criteria $\mathrm{L}_{0}<\mathrm{L}_{\mathrm{t}}$ diukur pada taraf signifikansi 
dan tingkat kepercayaan tertentu. Hipotesis yang diajukan dan akan diuji dalam uji normalitas ini sebagai berikut:

$\mathrm{H}_{\mathrm{o}}$ : data sampel berasal dari populasi yang berdistribusi normal

$\mathrm{H}_{\mathrm{a}}$ : data sampel berasal dari populasi yang tidak berdistribusi normal

Berdasarkan hasil perhitungan uji normalitas pretest dapat dilihat pada tabel 4.2.

\section{Tabel 4.2 Rekapitulasi Hasil Perhitungan}

Uji Normalitas Pretest dengan Uji liliefors

\begin{tabular}{|c|c|c|c|c|c|}
\hline Data & $\begin{array}{c}\text { Kelom } \\
\text { Pok }\end{array}$ & $\mathbf{L}_{\mathbf{0}}$ & $\mathbf{L}_{\mathbf{t}}$ & Kesimpulan & Ket \\
\hline \multirow{2}{*}{ Pretest } & Eksperimen & 0,1293 & 0,161 & Terima $\mathrm{H}_{\mathrm{o}}$ & Normal \\
\cline { 2 - 6 } & Kontrol & 0,1300 & 0,161 & Terima $\mathrm{H}_{\mathrm{o}}$ & Normal \\
\hline
\end{tabular}

Dilihat dari tabel 4.2 di atas diperoleh harga $L_{\text {hitung }}$ untuk kelas eksperimen adalah 0,1293 dan $L_{\text {tabel }}$ nya adalah 0,161 maka $L_{\text {hitung }}$ $<L_{\text {tabel }}(0,1293<0,161)$ dapat disimpulkan bahwa data pretest kelas eksperimen berdistribusi normal. Begitu juga dengan kelas kontrol yang memperoleh $L_{\text {hitung }}<L_{\text {tabel }}$ $(0,1300<0,161)$ maka dapat disimpulkan bahwa data pretest kelas kontrol berdistribusi normal.

\section{Tabel 4.3 Rekapitulasi Hasil Perhitungan}

Uji Normalitas posttest dengan Uji liliefors

\begin{tabular}{|c|c|c|c|c|c|}
\hline Data & Kelompok & $\mathbf{L}_{\mathbf{0}}$ & $\mathbf{L}_{\mathbf{t}}$ & Kesimpulan & Ket \\
\hline \multirow{2}{*}{ Posttest } & Eksperimen & 0,1230 & 0,161 & Terima $\mathrm{H}_{\mathrm{o}}$ & Normal \\
\cline { 2 - 6 } & Kontrol & 0,1115 & 0,161 & ${\text { Terima } \mathrm{H}_{\mathrm{o}}}^{\text {Normal }}$ \\
\hline
\end{tabular}

Dilihat dari tabel 4.3 di atas diperoleh harga $L_{\text {hitung }}$ untuk kelas eksperimen adalah 0,1230 dan $L_{\text {tabel }}$ nya adalah 0,161 maka $L_{\text {hitung }}$ $<L_{\text {tabel }}(0,1230<0,161)$ dapat disimpulkan bahwa data posttest kelas eksperimen berdistribusi normal. Begitu juga dengan kelas kontrol yang memperoleh $L_{\text {hitung }}<L_{\text {tabel }}$ $(0,1115<0,161)$ maka dapat disimpulkan bahwa data posttest kelas kontrol berdistribusi normal.

\section{Uji Homogenitas}

Uji homogenitas atau uji kesamaan dua varians populasi dilakukan dengan uji Fisher. Untuk kriteria pengujian data kedua sampel adalah homogen jika $\mathrm{F}_{\text {hitung }}<\mathrm{F}_{\text {tabel }}$ pada taraf signifikan 5\%. Rekapitulasi hasil perhitungan uji homogenitas dapat dilihat pada tabel 4.4 .

\section{Tabel 4.4 Rekapitulasi Hasil Perhitungan}

\section{Uji Homogenitas dengan Uji Fisher}

\begin{tabular}{|c|c|c|c|c|}
\hline Data & Kelompok & $\mathbf{F}_{\text {hitung }}$ & $\mathbf{F}_{\text {tabel }}$ & Kesimpulan \\
\hline \multirow{2}{*}{ Pretest } & Eksperimen & \multirow{2}{*}{1,08} & 1,86 & Homogen \\
\cline { 2 - 2 } & Kontrol & & & \\
\hline
\end{tabular}

Dilihat dari tabel $4.4 \mathrm{di}$ atas diperoleh harga $F_{\text {hitung }}$ untuk kelas eksperimen adalah 1,08 dan $F_{\text {tabel }}$ nya adalah 1,86 maka $F_{\text {hitung }}<$ $F_{\text {tabel }}(1,08<1,86)$ dapat disimpulkan bahwa data pretest kedua sampel homogen.

Tabel 4.5 Rekapitulasi Hasil Perhitungan

Uji Homogenitas dengan Uji Fisher

\begin{tabular}{|l|l|l|l|l|}
\hline Data & Kelompok & $\mathbf{F}_{\text {hitung }}$ & $\mathbf{F}_{\text {tabel }}$ & Kesimpulan \\
\hline
\end{tabular}




\begin{tabular}{|l|c|c|c|c|}
\hline \multirow{2}{*}{ Posttest } & Eksperimen & \multirow{2}{*}{1,04} & 1,86 & Homogen \\
\cline { 2 - 2 } & Kontrol & & & \\
\hline
\end{tabular}

Dilihat dari tabel 4.5 di atas diperoleh

\begin{tabular}{|c|c|c|c|c|}
\hline $\mathbf{r}_{\text {hitung }}$ & $\mathbf{r}_{\text {tabel }}$ & $\mathbf{N}$ & Hipotesis & Keterangan \\
\hline 0,15 & 0,37 & 30 & $\begin{array}{lr}\mathrm{r}_{\text {hitung }}<\mathrm{r}_{\text {tabel }} \\
\text { maka } & \mathrm{H}_{\mathrm{o}} \\
\text { ditolak dan } \mathrm{H}_{\mathrm{a}} \\
\text { diterima }\end{array}$ & $\begin{array}{l}\text { Terdapat } \\
\text { pengaruh model } \\
\text { pembelajaran } \\
\text { kooperatif tipe } \\
\text { Think Pair } \\
\text { Share (TPS) } \\
\text { terhadap } \\
\text { kemampuan } \\
\text { komunikasi } \\
\text { matematis } \\
\text { siswa }(r \neq 0)\end{array}$ \\
\hline
\end{tabular}

harga $F_{\text {hitung }}$ untuk kelas eksperimen adalah 1,04 dan $F_{\text {tabel }}$ nya adalah 1,86 maka $F_{\text {hitung }}<$ $F_{\text {tabel }}(1.04<1,86)$ dapat disimpulkan bahwa data posttest kedua sampel homogen.

\section{Pengujian Hipotesis}

Setelah uji prasyarat, maka didapat bahwa kedua kelas berdistribusi normal dan homogen. Selanjutnya dilakukan pengujian hipotesis. Pengujian hipotesis dilakukan pada data pretest dan postest melalui uji regresi linier sederhana. Untuk menentukan persamaan regresi linier yang menghubungkan antara pengaruh $\mathrm{X}$ (Kemampuan Komunikasi Matematis) terhadap variabel Y (Model Pembelajaran Think - Pair - Share ) dapat ditentukan dengan persamaan:

$$
\widehat{Y}=a+b X
$$

Model regresi linier antara Y (Model Pembelajaran Think - Pair - Share ) dengan $\mathrm{X}$ (kemampuan komunikasi matematis) dinyatakan dalam $\widehat{\mathrm{Y}}=\mathrm{a}+\mathrm{bX} . \quad$ Sehingga persamaan garis regresi adalah:

$$
\widehat{Y}=59,91+0,11 X \text {. }
$$

Pengujian hipotesis dalam penelitian ini menggunakan uji regresi dengan menggunakan data hasil kemampuan komunikasi matematis yang diperoleh siswa, yaitu data hasil pretest dan posttest. Hasil perhitungan dengan menggunakan uji regresi dibuat pada tabel berikut:

\section{Tabel 4.6 Hasil Uji Hipotesis}

Dari tabel 4.6 menunjukkan hasil perhitungan dengan menggunakan regresi, maka diperoleh $r_{\text {hitung }}=0,15$. Kemudian nilai tersebut dibandingkan dengan $r_{\text {tabel }}=0,37$ dengan $\mathrm{n}=30-2=28$ dan taraf signifikan $5 \%$. bila $r_{\text {hitung }} \leq r_{\text {tabel }}$ maka $H_{0}$ ditolak dan $H_{a}$ diterima, dengan demikian dapat disimpulkan terdapat pengaruh model pembelajaran pembelajaran kooperatif tipe Think Pair Share (TPS) terhadap kemampuan komunikasi matematis siswa.

\section{SIMPULAN}

Berdasarkan hasil penelitian yang diuraikan, maka dapat disimpulkan bahwa terdapat pengaruh model pembelajaran kooperatif tipe Think - Pair - Share (TPS ) terhadap kemampuan komunikasi matematis siswa kelas VIII SMP Negeri 4 Binjai Tahun Pelajaran 2017/2018. 


\section{DAFTAR PUSTAKA}

Abdul Majid. 2013. Strategi Pembelajaran. PT Ramaja Rosdakarya, Bandung.

Nurhikmah, dkk. 2016. Penerapan Model Pembelajaran Kooperatif Tipe ThinkPair - Share untuk Meningkatkan Kemampuan Komunikasi Matematis Pada Materi Aritmatika Sosial Siswa Kelas VII SMPNegeri 9 Palu . eJurnal Mitra Sains, Volume 4 Nomor 4, Oktober 2016 ) Hal 98.

Rusman. 2011. Cooperative Learning : Metode, Teknik, Struktur, dan Model Penerapan. Pustaka Pelajar, Yogyakarta.

Wirevenska, Ice. 2013. Upaya Meningkatkan Kemampuan Penalaran dan Komunikasi Matematik Siswa melalui Pendekatan Matematika Realistik di SMP Karya Bunda. Tesis PPS UNIMED. 